\title{
Impact of Heart Rot of Pericopsis elata (Harms) Van Meeuwen on Yield at Harvest in Production Forests in South-Eastern Cameroon
}

\author{
René Samuel Gweth Likaa1, Godswill Ntsomboh-Ntsefong2,3* Fridolin Choula1, Nnanga M. Ruth Laure ${ }^{2,3}$, \\ François Essouma Manga ${ }^{3}$, Jean-Lagarde Betti1 ${ }^{13}$, Alain Dongmo ${ }^{4}$, Ndongo Din ${ }^{1}$
}

${ }^{1}$ Department of Plant Biology, Faculty of Sciences, University of Douala, Douala, Cameroon

${ }^{2}$ Department of Plant Biology, Faculty of Sciences, University of Yaounde 1, Yaounde, Cameroon

${ }^{3}$ Institute of Agricultural Research for Development (IRAD), Yaounde, Cameroon

${ }^{4}$ Department of Biology of Animal Organisms, Faculty of Sciences, University of Douala, Douala, Cameroon

Email: ^ntsomboh@yahoo.fr

How to cite this paper: Likaa, R. S. G., Ntsomboh-Ntsefong, G., Choula, F., Laure, N. M. R., Manga, F. E., Betti, J.-L., Dongmo, A., \& Din, N. (2021). Impact of Heart Rot of Pericopsis elata (Harms) Van Meeuwen on Yield at Harvest in Production Forests in South-Eastern Cameroon. Open Journal of Forestry, 11, 315-329.

https://doi.org/10.4236/ojf.2021.113019

Received: May 1, 2021

Accepted: July 20, 2021

Published: July 23, 2021

Copyright $\odot 2021$ by author(s) and Scientific Research Publishing Inc. This work is licensed under the Creative Commons Attribution International License (CC BY 4.0).

http://creativecommons.org/licenses/by/4.0/

\begin{abstract}
This study of the impact of heart rot of Pericopsis elata on logging yield was conducted in Libongo, in three logging concessions of the Société d'Exploitation Forestière et Agricole du Cameroun (SEFAC). An inventory of 92 P. elata stumps in four Annual Cutting Areas (AACs) divided among three Forest Management Units (FMUs) distinguished by Minimum Operating Diameter (MOD) revealed that 22 stumps were rotten. Decay was visible on stumps with a diameter of more than $100 \mathrm{~cm}$ with a frequency of occurrence of $23.91 \%$, a percentage of abandonment of $55.20 \%$ and a yield of $44.79 \%$. The most important economic loss was revealed on 9 abandoned whole logs that cumulated a volume of $145.547 \mathrm{~m}^{3}$. The correlation between the diameter of the stumps and that of the decay gives a coefficient or correlation rate $\mathrm{r}=0.31$. The MOD for $P$. elata could be $80 \mathrm{~cm}$ and covers the biological risk class. The results indicate that $P$. elata shows an increasing gradient of decay rate with increasing tree diameter, resulting in a loss of material for larger diameter trees, and consequently a decrease in material yield at processing.
\end{abstract}

\section{Keywords}

Pericopsis elata, Minimum Operating Diameter, Heart Rot, Stump, Material Yield

\section{Introduction}

Pericopsis elata (Harms) Van Meeuwen, widely known under the trade names Assamela or Afrormosia, is a leguminous plant of the Fabaceae family. In Came- 
roon, its range is essentially limited to the eastern region, in the basins of the four rivers Dja, Boumba, Ngoko and Sangha (Vivien \& Faure, 1985). It is a heliophilic anemochore pioneer species (Hall \& Swaine, 1981; Bourland et al., 2012). Its hardwood of very high commercial value and often considered a substitute for teak, is highly valued on the international market and ranked among the four main species exported from Cameroon (Betti, 2008). In Cameroon, the FOB value of a cubic meter of $P$. elata is set at 156,100 FCFA according to Order No. 16/ 000533/CF/A/MINFI/DGD of September 2, 2016 establishing the FOB values of logs for export, and its calculated felling tax is set at $3 \%$ of its FOB value, i.e., the equivalent of 4683 FCFA (MINFI, 2020). It is mainly used for furniture and decorative veneers, interior and exterior joinery, parquetry and shipbuilding. It is also suitable for heavy and light construction, railroad sleepers.

The sustainability of $P$. elata management is problematic to the point of alarming the international community. This species has been the subject of several import suspensions from Congo Basin countries by the European Union (EU). It has been classified by the International Union for Conservation of Nature (IUCN) as an endangered species and logically listed in Appendix II of CITES (Convention on International Trade in Endangered Species of Wild Fauna and Flora) by decision of the $7^{\text {th }}$ Meeting of the Conference of the Parties in 1992. Guided by conservative measures and environmental caution, its Minimum Exploitation Diameter (MED) has been set at $100 \mathrm{~cm}$ in Cameroon. However, logging companies have questioned the quality of its timber harvested beyond this diameter due to heart rot and low volume harvested relative to potential (Belinga, 2009). P. elata trees with a diameter above $100 \mathrm{~cm}$ are rare, and the few that do exist have many heartwood defects (ITTO, 2008). To address this issue, the ITTO/CITES project enabled Cameroon to set up a vast multidisciplinary program in 2008 entitled "Sustainable management of Pericopsis elata in forest concessions and rehabilitation of old plantations", one of the activities of which was "the establishment of a research facility for the collection of data on the Biology and Ecology of $P$. elata in Cameroon" (Din, 2009). The first results obtained from this project contributed to the revision of its EMR, which was reduced to $90 \mathrm{~cm}$ in 2010 (Nnanga, 2019). However, very few scientific studies have been conducted on heart rot of this species as recommended by the project (Belinga, 2009). The objective of this study was therefore to contribute to the sustainable management of $P$. elata in the forests of the Congo Basin by improving knowledge on heart rot. More specifically, the aim was to determine the diameter classes most prone to heart rot and estimate the economic losses due to heart rot. The hypotheses were that the number of plants subject to rot increases with plant diameter; and more than half of the production is lost to rot.

\section{Materials and Method}

\subsection{Study Area and Ecological Factors}

The study site is located in three FMUs (Forest Management Units) of the SEFAC 
group (Figure 1). It is located in southeastern Cameroon and can be seen on topographic maps NA-33-XXII (Yokadouma) and NA-33-XVI (Moloundou) at a scale of 1:200,000. FMU 10008 covers an area of 72,727 ha. It is located between latitude $2^{\circ} 54^{\prime}$ and $3^{\circ} 12^{\prime}$ North and longitude $15^{\circ} 39^{\prime}$ and $16^{\circ} 03^{\prime}$ East. The area of FMU 10009 is $91,809.42$ ha and this FMU is located between latitudes $2^{\circ} 40^{\prime}$ and $3^{\circ} 20^{\prime}$ North and longitudes $15^{\circ} 40^{\prime}$ and $16^{\circ} 15^{\prime}$ East. FMU 10012 has an

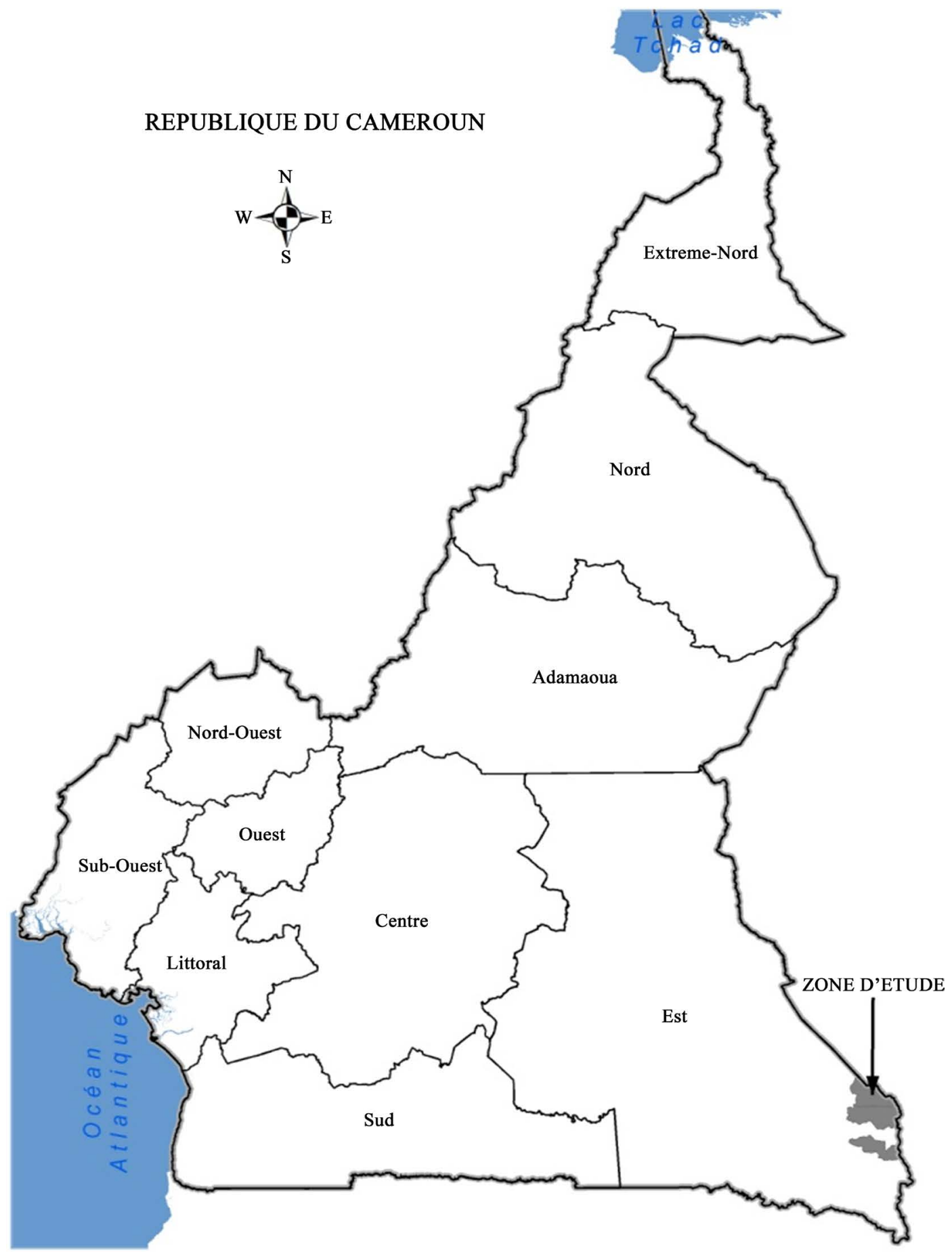

Figure 1. Location of study area. 
area of 59,063.92 ha and is located between the northern latitudes of $2^{\circ} 33^{\prime}$ and $2^{\circ} 38^{\prime}$ and the eastern longitudes of $15^{\circ} 39^{\prime}$ and $16^{\circ} 08^{\prime}$ (Figure 1 ).

This area is part of the Congolese Dja district, a domain of dense evergreen rainforest (Letouzey, 1985) and the "Dja-Odzala-Minkébé" landscape (De Wachter et al., 2009). The soil is a red or yellowish red oxisol with high clay content and iron and aluminum oxides (Battipaglia et al., 2015). It is influenced by a Guinean equatorial climate with two alternating rainy and dry seasons. Rainfall is spread throughout the year, with peaks in April and October. The average rainfall is $1500 \mathrm{~mm}$ /year. The average temperature is $25^{\circ} \mathrm{C}$ and relative humidity fluctuates between 60 and 90\% (Noupa \& Nkongmeneck, 2008). The choice of this study area was motivated by the presence of a distribution area of $P$. elata trees and already exploited logging sites, the authorization to cut the species at the DME corresponding to the interval of the study (Figure 2). The choice of FMUs was based on the EMR interval selected for this study. Three FMUs were selected according to this criterion: FMU 10008 (EMR $100 \mathrm{~cm}), 10009($ EMR $90 \mathrm{~cm})$ and 10012 (EMR $90 \mathrm{~cm}$ ).

\subsection{Sampling Method and Data Collection Process}

Four AACs (Annual Cutting Areas) were selected for this study. The distribution of these cutting areas in the three FMUs was done in the following manner:

- FMU 10008: two cutting areas, i.e., AAC 3-4 and 3-5;

- FMU 10009: one cutting block, i.e. AAC 4-1;

- FMU 10012: one cutting block, i.e. AAC 4-1.

Using the logging maps, the identification of felled $P$. elata trees was carried out in four harvesting blocks. The unique inventory identifier, counting unit number, and GPS coordinates of the tree were used to identify each stump. In the field, the number and date of felling were noted on each stump. This information was crucial for the traceability of logs from the different stumps counted from the felling site to the processing unit. For a given stump, the diameter of the stump was measured with a measuring tape. In cases of heart rot, the diameter of the rot was also measured. For cases of log abandonment due to rot, the length of the abutment or log and their diameters were measured to determine its volume.

\subsection{Data Analysis}

\section{Quantification of abandoned volumes in the forest}

To quantify the volume (Equation (1)) of wood abandoned due to heartwood decay at the felling site and at the level of the forest parks, the technique of wood cubing was used. The volume of each tree was calculated according to the following scale:

$$
V=\frac{1}{4} \pi D m^{2} L
$$

where: $V=$ tree volume $\left(\mathrm{m}^{3}\right)$; 

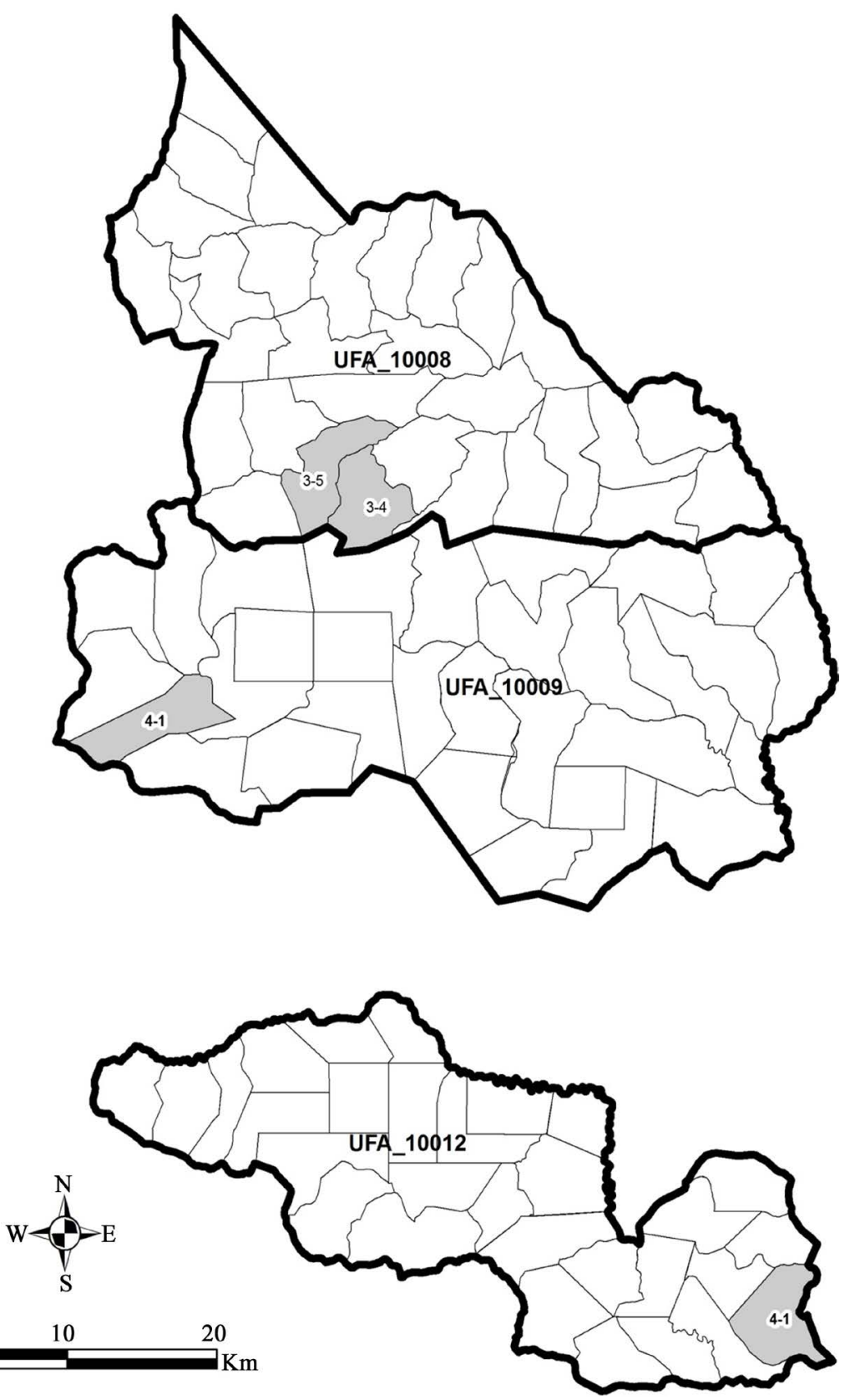

Figure 2. Location of study sites in each FMU.

$L=$ length of the tree shaft (m);

$D=$ average diameter of both ends of the log under bark;

$$
\frac{\pi}{4}=0.7854(\mathrm{~cm})
$$

By taking into account the volume actually taken out of the forest (2) or transported $(V t)$, the volume that could have been used at the factory can be determined if a volume ( $V a$ ) was not abandoned in the context of our study. This is obtained by:

$$
V T=V a+V t,
$$


where: $V T=$ Total Recoverable Volume;

$V a=$ Total Volume Abandoned;

$V t=$ Total volume transported.

The abandonment percentage (3) is given by the ratio:

$$
P a=\frac{\overline{V a}}{V T} \times 100
$$

where: $P a=$ percentage of abandonment or loss;

$\overline{V a}=$ Average volume abandoned.

Deducting the yield at exploitation, we will have (4):

$$
R d(\%)=100-P a
$$

\section{Calculation of the frequency}

The frequency is an indicator of the number of times in relation to the total of a value present in a statistical series. It is a number between 0 and 1 that can also be given as a percentage. It is given by the following formula (5) as:

$$
f(\%)=\frac{\text { effectif de la valeur }}{\text { effectif total }} \times 100
$$

\section{Correlation Coefficient}

The Bravais-Pearson correlation coefficient is a statistical index that expresses the intensity and direction (positive or negative) of the linear relationship between two quantitative variables. It is a measure of the linear relationship, i.e. the ability to predict one variable $x$ by another $y$ using a linear model. It measures the intensity of the link between two quantitative characteristics. It is therefore an important parameter in the analysis of linear regressions (simple or multiple). This coefficient is zero $(r=0)$ when there is no linear relationship between the variables (which does not exclude the existence of a relationship other than linear). Moreover, the coefficient has a positive sign if the relationship is positive (direct, increasing) and a negative sign if the relationship is negative (inverse, decreasing). This coefficient varies between -1 and +1 ; the intensity of the linear relationship will therefore be stronger the closer the value of the coefficient is to +1 or -1 , and weaker the closer it is to 0 (Zarrouk, 2012).

- A value close to +1 shows a strong link between the two traits. The linear relationship here is increasing (i.e. the variables vary in the same direction);

- A value close to -1 also shows a strong linkage but the linear relationship between the two traits is decreasing (the variables vary in the opposite direction);

- A value close to 0 shows an absence of linear relationship between the two characters.

The Bravais-Pearson coefficient ' $r$ ' between two variables $X$ and $Y$ is calculated from the covariance and standard deviations by applying the following formula (6):

$$
r_{x, y}=\frac{\operatorname{Cov}_{x, y}}{S_{x} \times S_{y}}
$$


where

$$
\operatorname{Cov}_{x, y}=\frac{\sum_{i}\left(x_{i}-m_{x}\right)\left(y_{i}-m_{y}\right)}{n}
$$

\section{Results}

\section{Inventory of $P$. elata stumps}

A total of 477 trees of $P$. elata with an average per AAFC of $119.25 \pm 103.34$ were inventoried in the three study sites (Figure 2). The number of individuals felled was 300 with an average of $75 \% \pm 80.16 \%$ or $62.89 \%$ of the exploitation rate. Overall, 92 stumps were inventoried with an average of $23 \% \pm 13.49 \%$ for a survey rate of $30.66 \%$ (Table 1). The number of stumps inventoried in the harvesting plots varied from 10 to 41 . The number of stumps inventoried was highest in cutblock 3-5 of FMU 10008 with 41 stumps. The survey rate was highest in cutblock 4-1 of FMU 10012 with $92.59 \%$.

Frequency of occurrence of rot as a function of EMR

During the inventory of $P$. elata stumps, the frequency of occurrence of heart

Table 1. Inventory of felled trees of $P$. elata.

\begin{tabular}{ccccccc}
\hline FMU & AAC & DMA & $\begin{array}{c}\text { Inventoried } \\
\text { trees }\end{array}$ & Felled trees & $\begin{array}{c}\text { Registered } \\
\text { stumps }\end{array}$ & Survey rate \\
\hline 10008 & $3-4$ & 100 & 232 & 189 & 16 & 8466 \\
& $3-5$ & & 179 & 72 & 41 & 56,944 \\
\hline 10009 & $4-1$ & & 12 & 12 & 10 & 83,333 \\
10012 & $4-1$ & & 54 & 27 & 25 & 92,593 \\
\hline Total & & & 477 & 300 & 92 & 30,667 \\
Mean & & & 11,925 & 75 & 23 & - \\
Standard deviation & & & 103,349 & 80,162 & 13,491 & - \\
\hline
\end{tabular}

Table 2. Inventory of rotting stumps according to DME.

\begin{tabular}{ccccccc}
\hline Diameter class & $\begin{array}{c}\text { Amplitude } \\
(\mathbf{c m})\end{array}$ & $\begin{array}{c}\text { Stumps } \\
\text { inventoried }\end{array}$ & $\begin{array}{c}\text { Stumps with } \\
\text { decay }\end{array}$ & $\begin{array}{c}\text { Stumps } \\
\text { abandoned }\end{array}$ & F (\%) & $\begin{array}{c}\text { Abandonment } \\
\text { rate }\end{array}$ \\
\hline I & {$[90-100[$} & 15 & 0 & 0 & 0 & 0.000 \\
II & {$[100-110[$} & 35 & 3 & 1 & 8571 & 2857 \\
III & {$[110-120[$} & 14 & 2 & 0 & 14,286 & 0.000 \\
IV & {$[120-130[$} & 14 & 7 & 0 & 50,000 & 0.000 \\
V & {$[130-140[$} & 7 & 3 & 2 & 42,857 & 28,571 \\
VI & {$[140-150]$} & 6 & 6 & 5 & 100 & 83,333 \\
VII & {$[150-160]$} & 1 & 1 & 1 & 100 & 100,000 \\
Total & & 92 & 22 & 9 & 23,913 & 9783 \\
Mean & & 13,143 & 3143 & 1286 & - & -
\end{tabular}


rot was observed as a function of DME. A total of 22 stumps with rot were inventoried with an average of $3.14 \pm 2.54$ stumps per... for a frequency of occurrence of $23.91 \%$ (Table 2). The diameter interval of the stumps from which the rot appears is [100 - 110[, with a high frequency of appearance in the interval [140 - 160] i.e. 100\% while the diameter interval of [90 - 100] has no occurrence of the rot (Figure 3). The heart rot of $P$. elata occurs, therefore, exclusively on individuals with an EMD $\geq 100 \mathrm{~cm}$. During the heart rot analysis, wood abandonments in the form of logs were recorded, with abutments neglected. A total of 9 logs were abandoned or an average of $1.28 \pm 1.79$ logs per... for an abandonment rate of $9.78 \%$. The log abandonments appear from the interval [100 110 [, and follow an exponentially increasing gradient as a function of the evolution of diameter (Figure 4).

Estimation of material loss of $P$. elata in the forest

A total of 22 logs were found to be infested with decay, of which 9 were whole logs found abandoned during the study, while 13 others were found to be

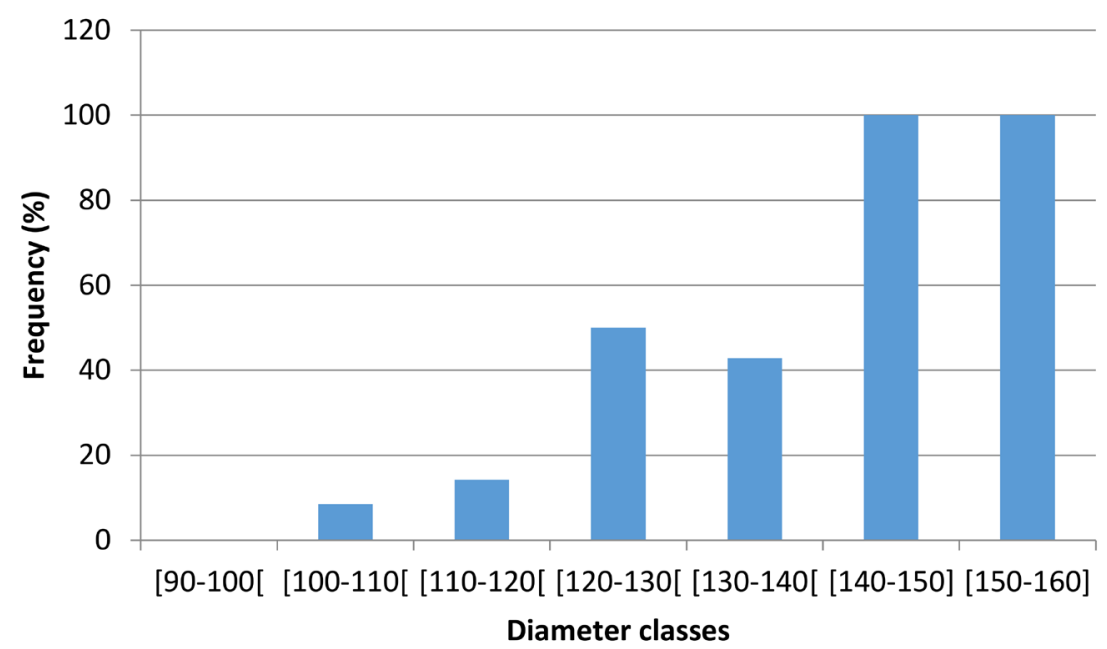

Figure 3. Incidence of heart rot of $P$. elata as a function of diameter classes.

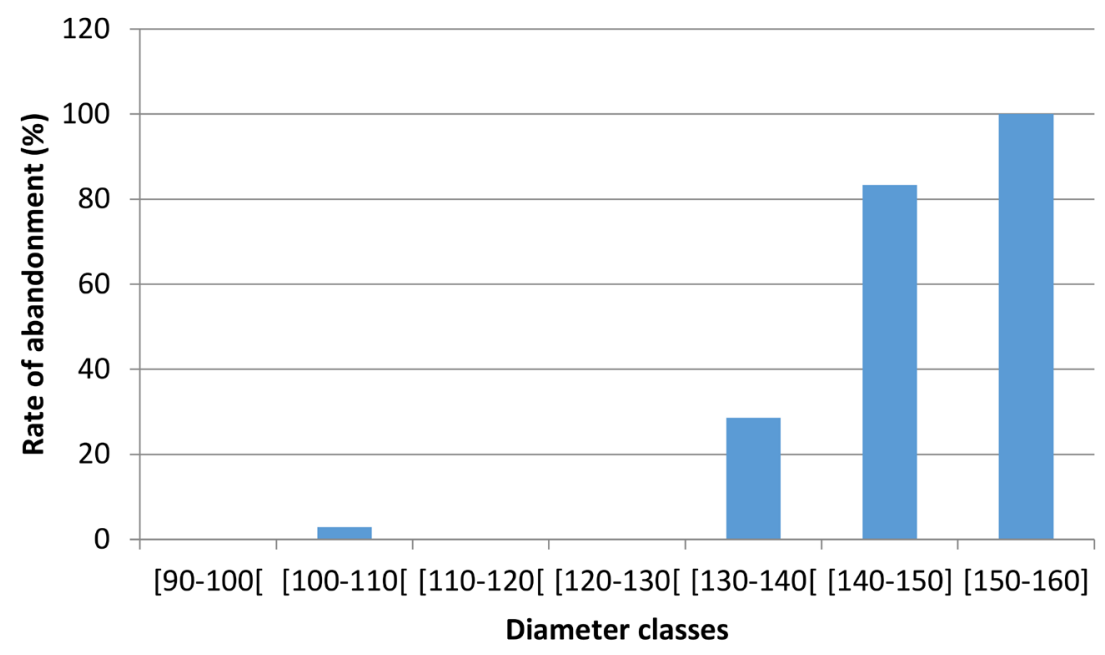

Figure 4. Wood abandonment rate as a function of DME. 
decayed but could be processed (Figure 5). The calculation of the loss of material of the 9 logs resulted in a loss of $145,547 \mathrm{~m}^{3}$ while the 13 logs with decay only resulted in a loss of $2.93 \mathrm{~m}^{3}$ for a total volume of material loss of $148,481 \mathrm{~m}^{3}$.

Economically, the losses for the state are of the order of 681,596 FCFA in terms of felling tax for the 9 abandoned logs and for the company of 87,328,200 FCFA according to the FOB value.

Taking into account the volume actually transported to the mill $(\mathrm{Vu})$, we determined the volume (VT), which is $268,974 \mathrm{~m}^{3}$ that could have been used if a volume $(\mathrm{Va})$ was not abandoned with an abandonment percentage $(\mathrm{Pa})$ of $55.20 \%$, which corresponds to an exploitation yield (Re) of $44.79 \%$. The yield losses appear from the interval [100 - 110[, but become more important from [130 - 140[ and evolve towards the most important peaks.

\section{Correlation coefficient}

The correlation coefficient between the diameter of the stumps and the rot of the stumps is $r=0.316$. The $n$ value represents the sample size which is 16 cases of rotting observed on the stumps.

The value of $p=0.023$ is the value of the test of significance of the slope or the probability of committing the alpha error. The value 0.05 corresponds to the significance level for this correlation. Heart rot is moderately correlated with tree diameter ( $\mathrm{p}$-value $=0.023<\alpha=0.05)$.

\section{Discussion}

\section{Inventory and frequency of decay occurrence as a function of EMD}

Timber harvesting in Cameroon is very selective, with an intensity of 1 tree or $10 \mathrm{~m}^{3}$ per hectare (Topa et al., 2010). Logging companies focus their harvesting on a reduced number of large-diameter, high-quality species in order to maximize their production. This explains their complaints about the lack of good quality resources for $P$. elata. Indeed, stems larger than $100 \mathrm{~cm}$ in diameter have many heartwood defects (Betti, 2008). The results obtained in this study confirm

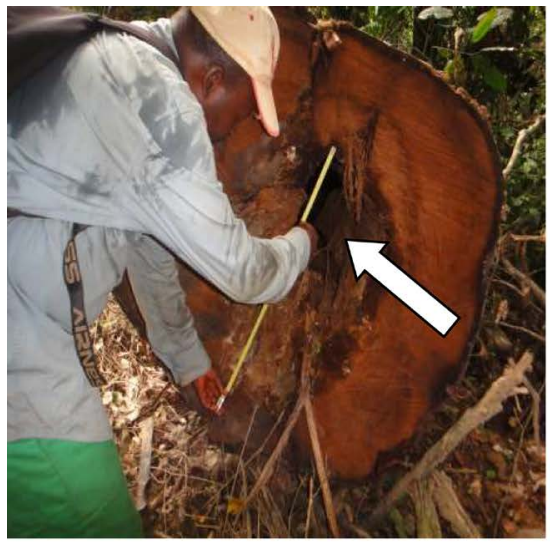

(a)

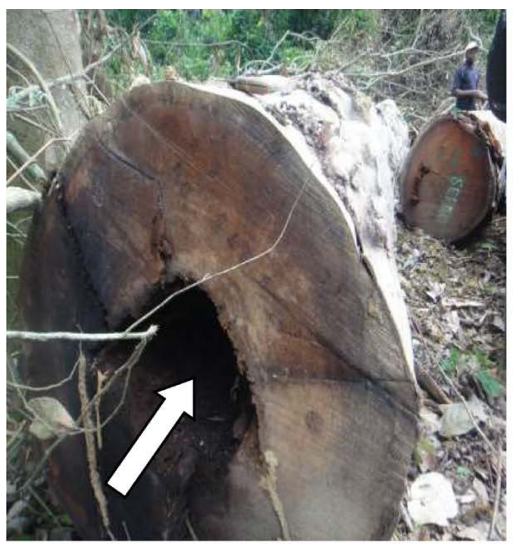

(b)

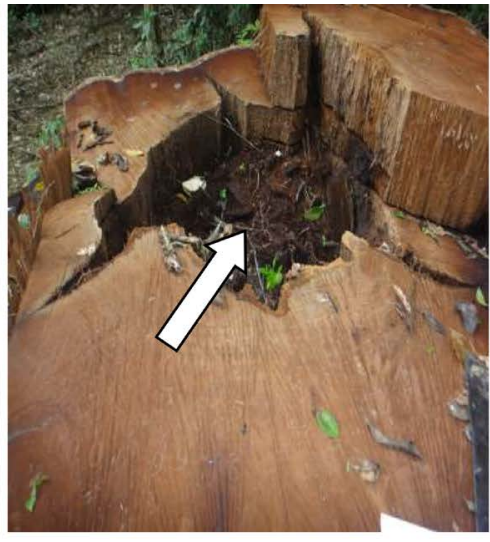

(c)

Figure 5. Logs and stump with heart rot (white arrow indicates the hollow left after heart rot). (a) Taking measurements on logs with holes; (b) Abandoned logs with holes; (c) Stump with heart rot. 
that the heartwood decay of $P$. elata attacks the large diameters of this species that are so much in demand by loggers. It appears from the diameter class [100 110 [, in the middle part of the trunk and evolves with an increasing gradient as the diameter of the tree increases. The work of Djeugap et al. (2017) also confirms these results where the evaluation of the susceptibility of $P$. elata trees to its heart rot studied with respect to three diameter classes, shows that it appears in the same range of diametric class. The occurrence of heart rot at this diameter interval could have an explanation with the calculation of its recovery rate. Indeed, it is higher than $50 \%$ from the diameter $50 \mathrm{~cm}$ and increases gradually to reach the optimum at $110 \mathrm{~cm}$ before starting to decrease (Belinga, 2009). This decline in the rate of reconstitution from the diameter interval [100 - 110[, would depend on the aging of the tree, which would favor the installation and development of decay agents. The tree has various natural defense mechanisms during active growth such as anatomical barriers, biochemical molecules (phytoanticipin and phytoalexin) and compartmentalization of decomposition within the trees (Shigo \& Tippett, 1981; Pearce, 1996). This natural defense is active up to a certain diametric threshold [100 - 110[, beyond which the tree loses its ability to naturally defend itself against wood-decay fungi. Aging is responsible for heartwood decay in P. elata, which favors the installation and development of wood-decay fungi. This result corroborates with that of (Bourland et al., 2012). Statistical analyses yield a moderately significant correlation between stump diameter and decay diameter (Table 3; Figure 6). This result suggests that aging of $P$. elata tree populations would not be the only parameter promoting the development of heart rot fungi. Benizry et al. (1988) reported that many other factors may be involved in the epidemiology of decay, including species composition, density, the nature of the forest and agricultural history, and edaphic factors.

\section{Loss of material and yield during exploitation}

The wood has the fullness of its qualities and is likely to be assigned to all the uses that can be reserved for it, only on the condition of being normal, of being healthy. Unfortunately, the wood often presents anomalies that are likely to alter and therefore lose the technological qualities. The most important alterations are of biological origin. They are due to living organisms that feed on the wood and transform it (Guinier, 1925). The alteration caused by fungi leads to a modification of the abnormal coloration of the wood but also its physical and mechanical properties which causes anomalies such as heart rot with a decrease in its market value (Fougerousse, 1958; Colling, 2002). These changes have negative effects on the yield of the species for forestry companies but also for the state. The most

Table 3. Correlation between tree diameter and heart rot diameter.

\begin{tabular}{ccccc}
\hline Variable & $\mathbf{n}$ & $\mathbf{r}$ & valeur de $\mathbf{p}$ & $\mathbf{0 . 0 5 0}=^{*}$ \\
Tree diameter & 16 & 0.31 & 0.023 & Significant result \\
Diameter of heart rot & & & & \\
\hline
\end{tabular}




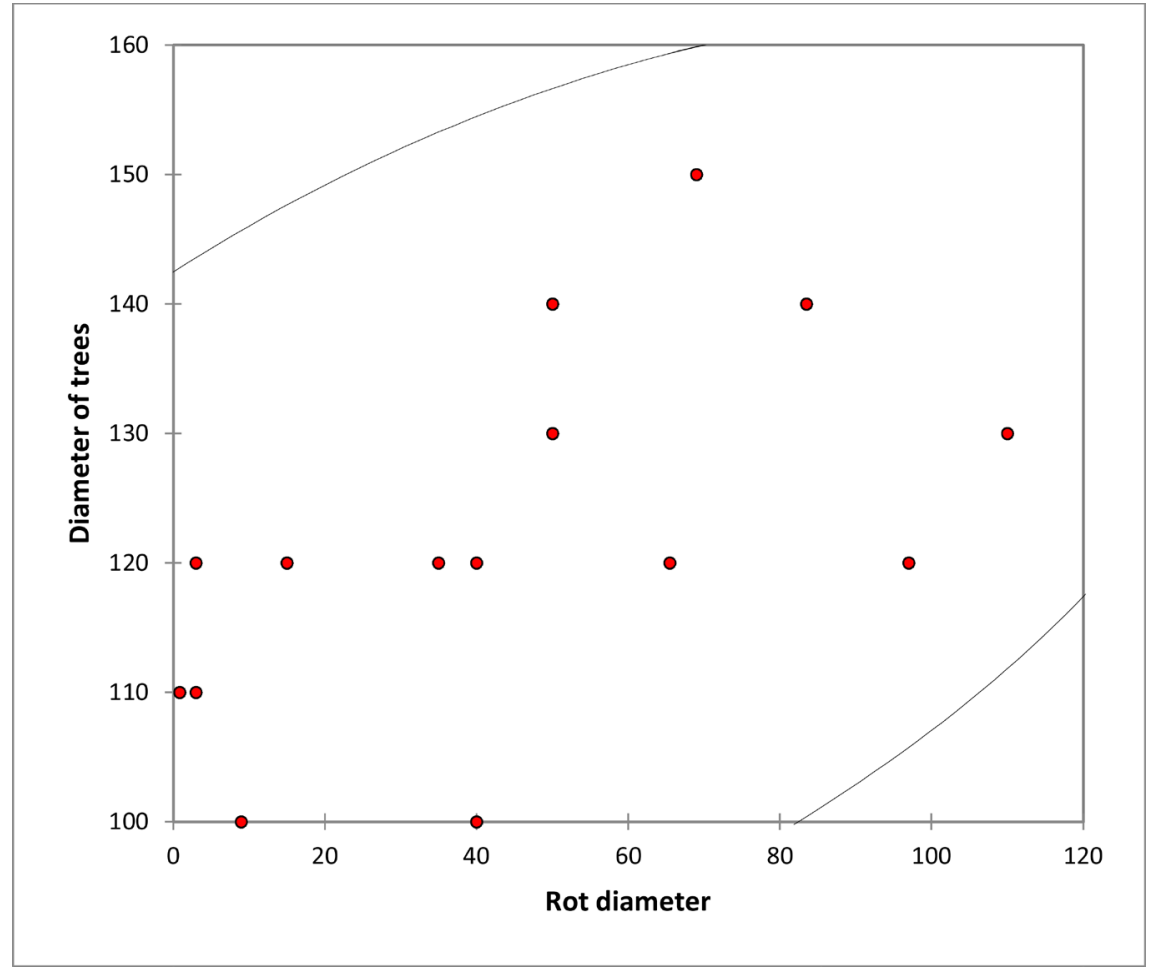

Figure 6. Evolution of heart rot as a function of diameter.

important loss was recorded only after felling where whole logs were left with important cavities appearing in the middle part of the trunk. These losses, estimated in the present study are higher than those recorded by Djeugap et al. (2017), which testifies to the seriousness of this phenomenon and the importance of its negative impact on the forest economy both at the state level and the private forestry sector.

Djeugap et al. (2017) also noted a high volume of timber loss with a progressive decrease as the diameter class decreased. This problem constitutes a significant loss of revenue for both logging companies and the Cameroonian state (Din, 2009).

\section{Determination of the DME of $P$. elata}

During the revision of the forestry code, the method used by companies to calculate sustainable harvesting parameters, such as the cutting cycle and the minimum harvesting diameter (DME), is taken into account (Cerutti et al., 2008; Picard et al., 2012). The rate of recovery analysis (\%RR) is the standard method for measuring the sustainability of logging and thus the effectiveness of these two parameters. However, it is important to remember that reconstitution is not the only metric to consider in the determination of DME based on diameter at breast height $(\mathrm{DBH})$. Fruiting diameter, seed dispersal, and other ecological conditions necessary for regeneration must also be considered (Mitchell, 2013). Another parameter to consider henceforth through this study is the definition of the concept of a species' biological risk class. It links the intrinsic quality of a wood and is defined from the knowledge of its natural resistance to the attack of 
biological agents of deterioration, and from the definition of natural durability classes (Jean, 1999). In addition, the DME must be economically viable. Analyzing the three parameters, Belinga (2009) reports that the recovery rate of P. elata starts to be higher than $50 \%$ from the $50 \mathrm{~cm}$ DME and gradually increases to peak at the $110 \mathrm{~cm}$ DME before starting to decrease. This suggests that only the 80,90 and $100 \mathrm{DBHs}$ can be retained for economically profitable and ecologically sound exploitation. If necessary, a threshold and a maximum limit could be set, as long as it is defined that economically unviable trees can continue to play other roles such as seed production.

Taking into account the effective flowering diameter, Bourland et al. (2012) placed it around $37 \mathrm{~cm}$ in diameter. The study on fruiting biometry reveals a high number of karyotypes in the interval ]70-80 $\mathrm{cm}$ [ with fruiting declining beyond the diameter $100 \mathrm{~cm}$ (Essono et al, 2017) corresponding to the decline of \%Re and the interval of occurrence of heart rot of Pericopsis elata.Knowing that biologically, the selected EMR must be at least $10 \mathrm{~cm}$ larger than the operational fruiting diameter (Durrieu, 2002), the EMR of Pericopsis elata could be 80 $\mathrm{cm}$, the economic imperatives of the exploitation of this species having been taken into account as well as the notion of biological risk class coverage which is [80 - 110]. These results complement the studies of Rajaspera (1998), which indicate that the tree suitable for harvesting must have reached the adult stage known as the minimum diameter of exploitability, which corresponds to the diameter below which a tree cannot be harvested profitably. It is determined at 80 $\mathrm{cm}$ in this study. It then specifies that during its development, the tree loses its value from a certain threshold called the optimal diameter of exploitability for which the optimum growth is reached and thus the optimum profitability which was determined at $110 \mathrm{~cm}$. Beyond this ceiling, the tree enters the stage of aging and becomes vulnerable to biological agents of deterioration and will end up in the stage of decay also called limit age. The heart rot of $P$. elata appears from the ageing stage which corresponds to the optimum diameter of exploitability and becomes vulnerable to the fungi responsible for the decay of the wood.

\section{Conclusion}

Tree diseases and pests in Africa and in other parts of the world are often neglected, although their cumulative effect has been recognized as the main cause of wood degradation, which reduces the volume of harvestable wood and lowers its quality, resulting in enormous economic losses in the forestry industry. In order for wood to retain its value, to provide all the services that we are entitled to expect from it, it is essential that the alterations be known, that their causes be defined and that we be able, to a large extent, to protect against them. In this study, it was determined that heartwood decay in $P$. elata increases with the senescence of the tree, favoring the development of mycelial filaments of the fungi that are responsible for the alteration of its heartwood with losses in its yield at harvest and a decrease in its market value. This study noted that the process of the dynamics of $P$. elata passes by a stage of natural durability where it has the capaci- 
ties of natural resistance vis-a-vis the attacks of the biological agents of deterioration and then reaches the optimal age of exploitability. Beyond this age, $P$. elata enters the stage of decay where it becomes vulnerable to fungi. From this point of view, it would be preferable to harvest wood from the threshold of the optimum harvestable age, which would give a high yield with healthy wood, rather than aging trees with a low volume of healthy wood. The results obtained from this work are insufficient to characterize the phenomenon of heart rot on trees in tropical forests, the case of $P$. elata being only epistolary to draw definitive conclusions and to propose axes to fight against this phenomenon. Further studies are to be encouraged in order to characterize all the phenomena responsible for heart rot on tropical forest trees and which have an impact on the economy of the forestry industry.

\section{Acknowledgements}

Authors thank the SEFAC group located in southeastern Cameroon for granting access to their Forest Management Units where this study was undertaken. Moreover, the comments and suggestions from reviewers have greatly helped the authors to improve the quality of this paper. We appreciate their rigorous and conscientious efforts, and hereby present our sincere thanks to them.

\section{Conflicts of Interest}

The authors declare no conflicts of interest regarding the publication of this paper.

\section{References}

Battipaglia, G., Zalloni, E., Castaldi, S., Marzaioli, F., Cazzolla-Gatti, R., \& Lasserre, B. (2015). Long Tree-Ring Chronologies Provide Evidence of Recent Tree Growth Decrease in a Central African Tropical Forest. PLoS ONE, 10, e0120962. https://doi.org/10.1371/journal.pone.0120962

Belinga, S. J. (2009). Gestion durable de Pericopsis elata (Assamela) dans les forêts de production au Cameroun. Etude du potentiel. Projet OIBT/CITES sur la gestion durable de P. elata dans le bassin du Congo (41 p.). Yaoundé.

Benizry, E., Durrieu, G., \& Rouane, P. (1988). La pourriture du cœur de l'Epicea, Picea abies (L) Karst en Auvergne. Annales des Sciences Forestières, 45, 141-156. https://doi.org/10.1051/forest:19880204

Betti, J. L. (2008). Non Detriment Findings Report on Pericopsis elata (Fabaceae) in Cameroon (59 p.). NDF Workshop Case Study 2 (Mexico).

Bourland, N., Kouadio, Y. L., Fétéké, F., Lejeune, P., \& Doucet, J.-L. (2012). Ecology and Management of Pericopsis elata (Harms) Meeuwen (Fabaceae) Populations: A Review. Biotechnology, Agronomy and Society and Environment, 16, 486-498.

Cerutti, P. O., Nasi, R., \& Tacconi, L. (2008). Sustainable Forest Management in Cameroon Needs More than Approved Forest Management Plans. Ecology and Society, 13, 36. https://doi.org/10.5751/ES-02591-130236

Colling, C. (2002). Les champignons du bois (10 p.).

De Wachter, P., Malonga, R., Moussavou, M. B. L., Nishihara, T., Nzooh, Z., \& Usongo, 
L. (2009). Dja-Odzala-Minkebe (Tridom). In C. De Wasseige, D. Devers, P. De Marcken, R. Eba'a Atyi, R. Nasi, \& P. Mayaux (Eds.), Les Forêts du Bassin du Congo: Etat des Forets 2008 (pp. 277-292). Office des publications de l'Union européenne.

Din, N. (2009). Mise en place d'un dispositif de recherche pour la collecte des données sur la Biologie et l'Ecologie de Pericopsis elata (Assamela) au Cameroun (77 p.). Projet OIBT/ CITES sur la gestion durable de Pericopsis elata (Assamela) dans le Bassin du Congo.

Djeugap, F. J., Ngoune, D. P. F., Ntabe, N. E., \& Gweth, L. R. S. (2017). Susceptibility of Pericopsis elata (Assamela) to Heartwood Decay and Identification of Micro and Macro Fungi Associated with the Disease in Cameroon. Annals of Plants Sciences, 6, 17511757. https://doi.org/10.21746/aps.2017.6.11.6

Durrieu De Madron (2002). Mode de calcul des paramètres pour l'élaboration des plans d'aménagement. CIRAD-Forêt/Forêt Ressources Management. Document de travailVersion 1 (71 p.).

Essono, D., Nwaga, D., \& Kono, L. D. (2017). Phénologie fruitière de Pericopsis elata dans la forêt dense humide de Zoulabot et Bidou (Cameroun). World Wide Journal of Multidisciplinary Research and Development (WWJMRD), 3, 74-88.

Fougerousse, M. (1958). Les altérations fongiques des bois frais en Afrique Tropicale et plus particulièrement de l'Ilomba et du Limba. Revue Bois et Forêts des Tropiques, 60, 41-56.

Jean, G. (1999). Comportement et caractéristiques technologiques des bois de forêt naturelle: Evolution des méthodes d'étude en relation avec l'adéquation qualité-usages. Séminaire FORAFRI Libreville-session 3: Produits de la forêt, CIRAD-Forêt, 13 p.

Guinier, P. (1925). Les altérations des Bois et leurs remèdes. Revue de botanique appliquée et d'agriculture coloniale, 5, 684-696. https://doi.org/10.3406/jatba.1925.4327

Hall, J. B., \& Swaine, M. D. (1981). Distribution and Ecology of Vascular Plants in a Tropical Rainforest: Forest Vegetation in Ghana (p. 383). The Hague: W. Junk Publishers.

ITTO (2008). Ensuring That International Trade in Pericopsis elata Is Not Detrimental to Its Conservation in the Congo Basin. Report of the Training Workshop on Sustainable Trade of Pericopsis elata, Kribi, 2-4 April 2008, 69 p.

Letouzey, R. (1985). Notice de la carte phytogéographique du Cameroun au 1:500.000: Domaine de la forêt dense humide toujours verte (pp. 95-142). Toulouse: ICIV.

MINFI (2020). Loi $n^{\circ} 2020 / 018$ du 17 décembre 2020 portant loi de finances de la République du Cameroun pour l'exercice 2021 (73 p.).

Mitchell, W. (2013). Calcul des diamètres minimum d'exploitation durable: Méthode prenant en compte les types de forêt et l'historique d'exploitation au Cameroun. Master 2 en agronomie et agroalimentaire, spécialité gestion environnementale des écosystèmes et forêts tropicales, 47 p+annexes.

Nnanga, M. R. L. (2019). Régénération naturelle de Pericopsis elata HARMS VAN MEEUWEN (Fabacées) en forêts de production au Sud-Est du Cameroun (71 p.). Thèse de Doctorat/PhD en Biologie des Organismes Végétaux.

Noupa, P., \& Nkongmeneck, B. A. (2008). Influence des clairières forestières sur la répartition spatiale des grands mammifères dans la forêt dense du Bassin du Congo: Cas du Parc National de Boumba-Bek (Sud-Est Cameroun). International Journal of Biological and Chemical Sciences, 2, 185-195. https://doi.org/10.4314/ijbcs.v2i2.39734

Pearce, R. B. (1996). Antimicrobial Defenses in the Wood of Living Trees. New Phytologist, 132, 203-233. https://doi.org/10.1111/j.1469-8137.1996.tb01842.x

Picard, N., Laurent, S.-A., \& Matieu, H. (2012). Manuel de construction d'équations allométriques pour l'estimation du volume et la biomasse des arbres. De la mesure de 
terrain à la prediction (215 p.). FAO; Food and Agricultural Organization of the United Nations.

Rajaspera, B. T. Y. (1998). Etude architecturale de quelques essences forestières pour la determination des dimensions d'exploitabilité (82 p.). Université d'Antananarivo, Ecole supérieure des Sciences Agronomiques, departement des Eaux et Forêt.

Shigo, A., \& Tippett, J. T. (1981). Compartmentalization of American Elm Tissues Infected by Ceratocystis ulmi. Plant Disease, 65, 715-718.

https://doi.org/10.1094/PD-65-715

Topa, G., Karsenty, A., Megevand, C., \& Debroux, L. (2010). Forêts tropicales humides du Cameroun: Une décennie de réformes (232 p.). Washington DC: Banque Mondiale. https://doi.org/10.1596/978-0-8213-7879-3

Vivien, J., \& Faure, J. J. (1985). Arbres des Forêts denses d'Afrique Centrale (551 p.). Paris: Ministère des Relations Extérieures, Coopération et Développement-ACCT.

Zarrouk, F. (2012). Etude de la relation entre deux variables: Le coefficient de corrélation de Bravais-Pearson (2 p.). 